\title{
JOURNAL OF DINDA
}

Kelompok Keahlian Rekayasa Data

Institut Teknologi Telkom Purwokerto

Vol. 1 No. 2 (2021) 52 - 62

ISSN Media Elektronik: -

\section{IMPLEMENTASI DEEP LEARNING UNTUK KLASIFIKASI CITRA UNDERTONE MENGGUNAKAN ALGORITMA CONVOLUTIONAL NEURAL NETWORK}

\author{
Rizka Fayyadhila ${ }^{1}$, Apri Junaidi ${ }^{2}$, Novian Adi Prasetyo ${ }^{3}$ \\ ${ }^{1}$ Program Studi S1 Teknik Informatika, Fakultas Informatika, Institut Teknologi Telkom Purwokerto \\ ${ }^{2}$ Program Studi S1 Sains Data, Fakultas Informatika, Institut Teknologi Telkom Purwokerto \\ ${ }^{3}$ Jurusan, fakultas, institusi \\ ${ }^{1} 17102187 @$ ittelko-pwt.ac.id, ${ }^{2}$ apri@ittelkom-pwt.ac.id, ${ }^{3}$ novian@ittelkom-pwt.ac.id
}

\begin{abstract}
The beauty of Indonesian women is distinguished by skin color, facial structure, hair color and body posture. For women today trying to look beautiful is a must. The way to make yourself look beautiful can be tricked by using make-up. But it's not that easy to use make-up because the type of make-up is differentiated based on the basic skin color, this is the problem for women in using make-up. Undertone is the basic color of the skin, there are three types of undertones, namely warm, cool and neutral. By knowing the type of undertone, it will make it easier for women to use make-up, namely to determine the appropriate shade based on the type of undertone. For this reason, a modeling of undertone image classification was made using the Convolutional Neural Network algorithm. This algorithm is claimed to be the best algorithm for solving object recognition and detection problems. The wrist vein color image dataset is required. The dataset used is 30 data per class, then preprocessing is carried out by homogenizing the image size to $64 \times 64$ pixels, then augmentation is carried out on each image by rotating and zooming. At this stage, the dataset will be divided into 3000 images which are divided into $80 \%$ training data and $20 \%$ testing data. Then it is processed through the convolution and pooling process at the feature learning stage, then the fully connected layer and classification stage where the feature learning results will be used for the classification process based on subclasses. Produces accuracy and training model values reaching $98 \%$ with a loss value of 0.0214 and for accuracy from data validation it reaches $99 \%$ with a loss value of 0.0239 with model testing results of $99.5 \%$.
\end{abstract}

Keywords: Undertone, Make up, Convolutional Neural Network

\begin{abstract}
Abstrak
Kecantikan perempuan Indonesia dibedakan berdasarkan warna kulit, struktur wajah, warna rambut dan postur tubuh. Bagi perempuan pada zaman sekarang berusaha tampil cantik dan menarik adalah suatu keharusan. Cara untuk membuat diri terlihat cantik dan menarik bisa diakali dengan penggunaan make up. Tapi tidak semudah itu dalam penggunaan make up karena jenis make up dibedakan berdasarkan warna dasar kulit, ini lah yang menjadikan permasalahan untuk perempuan dalam penggunaan make up. Undertone merupakan warna dasar kulit, terdapat tiga jenis undertone yaitu warm, cool dan neutral. Dengan mengetahui tipe undertone maka akan mempermudah perempuan dalam penggunaan make up yaitu untuk menentukan shade yang cocok berdasarkan tipe undertone. Untuk itu dibuatlah sebuah pemodelan klasifikasi citra undertone menggunakan algoritma Convolutional Neural Network. Algoritma ini diklaim sebagai algoritma terbaik untuk memecahkan masalah objek recognition dan detection. Diperlukan dataset citra warna urat nadi pada pergelangan tangan. Dataset yang digunakan berjumlah 30 data tiap kelasnya, kemudian dilakukan preprocessing dengan menyeragamkan ukuran gambar menjadi 64x64 pixel, selanjutnya dilakukan augmentasi pada setiap gambar dengan cara rotate dan zoom. Pada tahap ini akan dilakukan pembagian dataset dengan jumlah 3000 gambar yang dibagi menjadi $80 \%$ data training dan $20 \%$ data testing. Kemudian diproses melalui konvolusi dan proses pooling pada tahapan feature
\end{abstract}

Diterima Redaksi : 01-09-2021 | Selesai Revisi : 03-09-2021 | Diterbitkan Online : 04-09-2021 
learning, selanjutnya tahap fully connected layer dan classification dimana hasil feature learning akan digunakan untuk proses klasifikasi berdasarkan subclass. Menghasilkan nilai accuracy dan training model mencapai $98 \%$ dengan nilai loss sebesar 0,0214 dan untuk accuracy dari data validation mencapai 99\% dengan nilai loss sebesar 0,0239 dengan hasil pengujian model sebesar 99,5\% .

Kata kunci: Undertone, Make up, Convolutional Neural Network

(C) 2021 Jurnal DINDA

\section{Pendahuluan}

Indonesia adalah sebuah negara yang luas dengan berbagai macam suku, etnis, ras, sosial-budaya dan agama. Keanekaragaman ini yang menjadikan bahwa Indonesia mempunyai kekayaan dan keindahan negaranya, sehingga mampu memberikan warna bagi rakyat Indonesia. Berdasarkan hasil dari kerja sama Badan Pusat Statistik (BPS) dan Institut of South Asian Studies (ISEAS) merumuskan bahwa terdapat sekitar 633 suku yang diperoleh dari pengelompokan suku dan sub suku yang ada di Indonesia [1].

Warna kulit yang dimiliki setiap perempuan merupakan kecantikan yang natural, yang menjadi ciri khas setiap individu. Pada zaman sekarang bagi kaum perempuan berusaha tampil menjadi cantik dan menarik adalah suatu keharusan. Salah satu aspek untuk membuat diri terlihat cantik dan menarik bisa diakali dengan penggunaan make up [4]. Padahal untuk membuat diri terlihat cantik bisa diakali dengan penggunaan make up dan berpenampilan menarik. Make up tersendiri adalah merias wajah dengan menyamarkan bagian yang kurang sempurna dan menonjolkan bagian yang sudah baik [5].

$\begin{array}{lccr}\text { Citra-citra tersebut dikonstruksikan } & \text { serta } \\ \text { disosialisasikan melalui } & \text { media iklan, dengan }\end{array}$ memasarkan produk make up seperti foundation, lipstick, BB Cream, CC Cream dan lain sebagainya yang bertujuan untuk menunjang penampilan perempuan sehingga tetap up to date atau kekinian. Namun dalam memperbaiki penampilan, setiap perempuan harus pandai bermake up. Dalam hal ini banyak perempuan yang kesulitan untuk menggunakan make up.

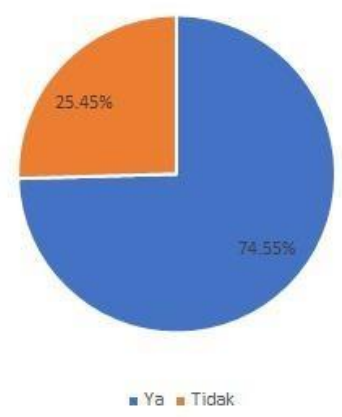

Gambar 1 Diagram Persentase Hasil Survey

Gambar 1.1 merupakan diagram lingkaran hasil survey tentang seberapa banyak yang kesulitan dalam penggunaan make up. Dari 55 responden didapatkan $74,55 \%$ menyatakan bahwa responden kesulitan dalam penggunaan make up dan $25,45 \%$ menyatakan bahwa tidak kesulitan dalam penggunaan make up. Maka dari hasil survey tersebut dinyatakan bahwa banyak yang kesulitan dalam penggunaan make up.

Kesulitan dalam menggunakan make up dikarenakan banyaknya jenis make up yang dibedakan berdasarkan warna dasar kulit atau undertone. Dari sinilah muncul permasalahan perempuan yang kebingungan saat memilih shade atau warna make up yang sesuai dengan tipe undertone yang dimiliki. Perempuan yang salah dalam memilih shade make up terkadang menjadi tidak percaya diri, karena warna make up yang dipakai berbeda jauh dengan warna kulit yang dimiliki sehingga membuat penampilan mereka malah terlihat buruk.

Undertone merupakan warna dasar kulit yang ditentukan oleh gen atau keturunan yang dipengaruhi oleh zat yang disebut melanin. Hal ini menandakan bahwa undertone kulit tidak akan beruba meski warna kulit berubah menjadi cenderung gelap akibat dari paparan sinar matahari atau lebih cerah karena pemakaian skincare. Setiap orang yang memiliki warna kulit hampir sama bukan berarti memiliki undertone kulit yang sama. Undertone kulit, terbagi menjadi tiga jenis yaitu cool, neutral dan warm. Undertone dapat diketahui dengan melihat warna urat nadi yang ada pada pergelangan tangan bagian bawah. Dengan mengetahui tipe undertone maka akan mempermudah untuk menentukan shade make up yang sesuai dan akan menjadikan perempuan tampil lebih percaya diri [8].

Dengan teknologi dapat mengadopsi proses dan cara berpikir manusia atau yang sering disebut dengan teknologi kecerdasan buatan (artificial intelligence). Dari kecerdasan buatan tersebut dapat mengklasifikasikan tipe undertone berdasarkan warna urat nadi yang dimiliki setiap perempuan. Ada banyak sekali cabang kendali cerdas yang bisa ditemui, yaitu cabang ilmu pembelajaran mesin (machine learning) yang terdiri dari algoritma pemodelan abstraksi tingkat tinggi pada data, menggunakan sekumpulan fungsi transformasi non-linear yang ditata berlapis-lapis dan mendalam. Istilah dari pembelajaran mendalam tersebut dinamakan Deep Learning.

Deep learning adalah sebuah cabang keilmuan baru dalam machine learning yang akhir-akhir ini 
berkembang karena pengembangan teknologi General Purpose Graphical Processing Unit (GPGPU). Deep learning mempunyai kemampuan yang sangat baik dalam visi komputer, salah satunya adalah klasifikasi objek citra. Dengan mengimplementasikan salah satu metode machine learning yang dapat digunakan untuk klasifikasi objek citra yaitu Convolutional Neural Network (CNN) [10].

CNN adalah pengembangan dari Multilayer Perceptron (MLP) yang didesain untuk mengolah data dua dimensi. 2 CNN termasuk dalam jenis Deep Neural Network karena kedalaman jaringan yang tinggi dan banyak diaplikasikan pada data citra. Sebuah CNN dapat melakukan pengenalan citra dengan akurasi yang menyaingi manusia pada dataset tertentu. Algoritma ini diklaim sebagai algoritma terbaik untuk memecahkan masalah objek recognition dan detection. CNN merupakan suatu layer yang memiliki susunan neuron 3D (lebar, tinggi, kedalaman). Lebar dan tinggi merupakan ukuran layer sedangkan kedalaman mengacu pada jumlah layer [11].

Oleh Karena itu untuk mempermudah permasalah pada perempuan dibuatlah suatu pemodelan untuk mengklasifikasikan tipe undertone berdasarkan citra gambar warna urat nadi yang terdapat pada pergelangan tangan setiap perempuan dengan menggunakan algoritma CNN serta dapat diimplementasikan dalam bentuk aplikasi website. Berikut adalah skema penjabaran penelitian yang terbagi menjadi dua.

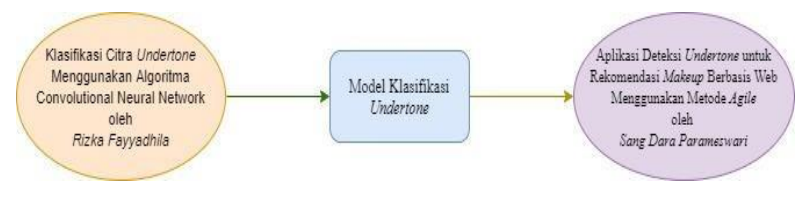

Gambar 1.1 Skema penjabaran penelitian

Pada Gambar 1.2 merupakan penjabaran pembagian tugas dalam mengimplementasikan pendeteksi tipe undertone ke dalam bentuk website yang dibagi menjadi yang pertama adalah pembuatan pemodelan klasifikasi cita undertone menggunakan algoritma $\mathrm{CNN}$ dan bagian kedua adalah sistem rancang bangun menggunakan metode Agile.

Artikel hendaknya memuat tulisan yang berisi 1 . Pendahuluan, 2. Metode Penelitian (bisa meliputi analisis, arsitektur, metode yang dipakai untuk menyelesaikan masalah, implementasi), 3. Hasil dan Pembahasan, 4. Kesimpulan, 5. Ucapan terimakasih (kalau ada) dan Daftar Rujukan.

Berdasarkan dari alasan dan penelitian tersebut, maka pertanyaan-pertanyaan yang muncul pada penelitian ini adalah sebagai berikut:
. Bagaimana implementasi algoritma CNN untuk mengklasifikasikan citra undertone?

2. Seberapa besar akurasi yang didapatkan dari hasil klasifikasi menggunakan algoritma $\mathrm{CNN}$ ?

\section{Metode Penelitian}

Alur proses penelitian pada implementasi deep learning untuk klasifikasi citra undertone menggunakan algoritma convolutional neural network seperti Gambar

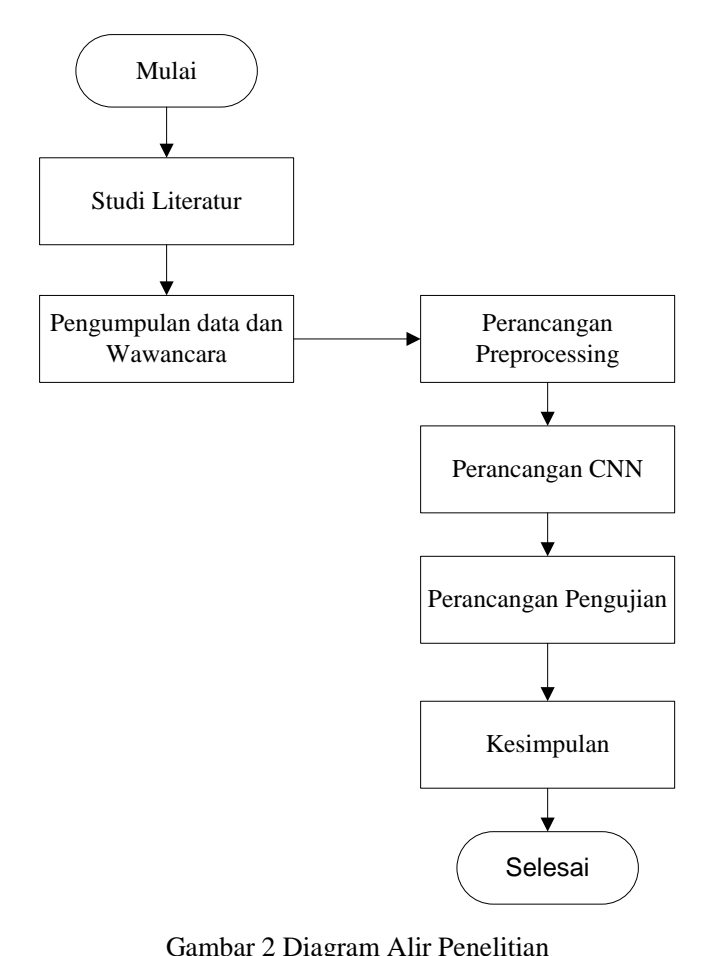

Jelaskan metode preparasi dan teknik karakterisasi yang digunakan. Jelaskan dengan ringkas, tetapi tetap akurat seperti ukuran, volume, replikasi dan teknik pengerjaan. Untuk metode baru harus dijelaskan secara rinci agar peneliti lain dapat mereproduksi percobaan. Sedangkan metode yang sudah mapan bisa dijelaskan dengan memetik rujukan.

\section{Studi Literatur}

Pada tahap awal ini dilakukan mengenai studi literatur dari berbagai sumber yang tersedia seperti jurnal, skripsi, buku, website maupun sumber lain yang memiliki keterkaitan dengan permasalahan yang dihadapi.

\section{Pengumpulan Data}

Pada tahap pengumpulan data untuk mencari data-data citra warna urat nadi yang dimiliki perempuan di beberapa daerah di Indonesia yaitu dengan cara manual seperti pengambilan gambar warna urat nadi pada pergelangan tangan menggunakan kamera smartphone. Setelah pengumpulan data kemudian dilakukan wawancara dengan pakar atau ahli dibidangnya untuk 
menambah informasi yang lebih akurat dalam membedakan tipe undertone yang dibagi menjadi tiga kelas yaitu cool, warm, dan neutral.

3. Perancangan Preprocessing

Pada tahap selanjutnya, data yang telah diperoleh akan dilakukan proses preprocessing. Preprocessing yang akan dilakukan pada penelitian ini yaitu menyeragamkan ukuran gambar menjadi $64 \times 64$ pixel, kemudian dilakukan augmentasi pada setiap gambar dengan cara rotate, dan zoom. Pada tahap ini akan dilakukan pembagian dataset dengan jumlah 3000 gambar yang akan dibagi menjadi $80 \%$ untuk data training dan $20 \%$ data testing.

\begin{tabular}{ccc}
\multicolumn{2}{c}{ Table 2 } & Augmentasi Jumlah Dataset \\
\hline Label & Data Asli & $\begin{array}{c}\text { Hasil } \\
\text { Augmentasi }\end{array}$ \\
\cline { 2 - 3 } & Jml Orang & Aum \\
\hline Cool & 36 & $17-18,4$ \\
Neutral & 32 & $18,5-25$ \\
Warm & 37 & \\
\hline
\end{tabular}

\begin{tabular}{|c|c|c|}
\hline Keterangan & Rasio & Jumlah \\
\hline Data Train & 0,8 & 2400 \\
\hline Data Test & 0,2 & 6000 \\
\hline
\end{tabular}

4. Rancangan Convolutional Neural Network (CNN) Setelah dilakukan pembuatan data, langkah selanjutnya melakukan model CNN. Umumnya dalam CNN memiliki 2 tahapan, yaitu tahap feature learning dan classification. Input gambar pada model CNN menggunakan citra yang berukuran 64x64.Citra masukan kemudian akan diproses terlebih dahulu melalui proses konvolusi dan proses pooling pada tahapan feature learning. Setiap konvolusi memiliki jumlah filter dan ukuran kernel yang berbeda. Kemudian dilakukan proses flatten atau proses mengubah feature map hasil pooling layer kedalam bentuk vector. Proses ini disebut dengan tahap fully connected layer. Berikut adalah rancangan dari arsitektur $\mathrm{CNN}$ pada penelitian ini:
Table 2.2 Diagram Alir Arsitektur CNN

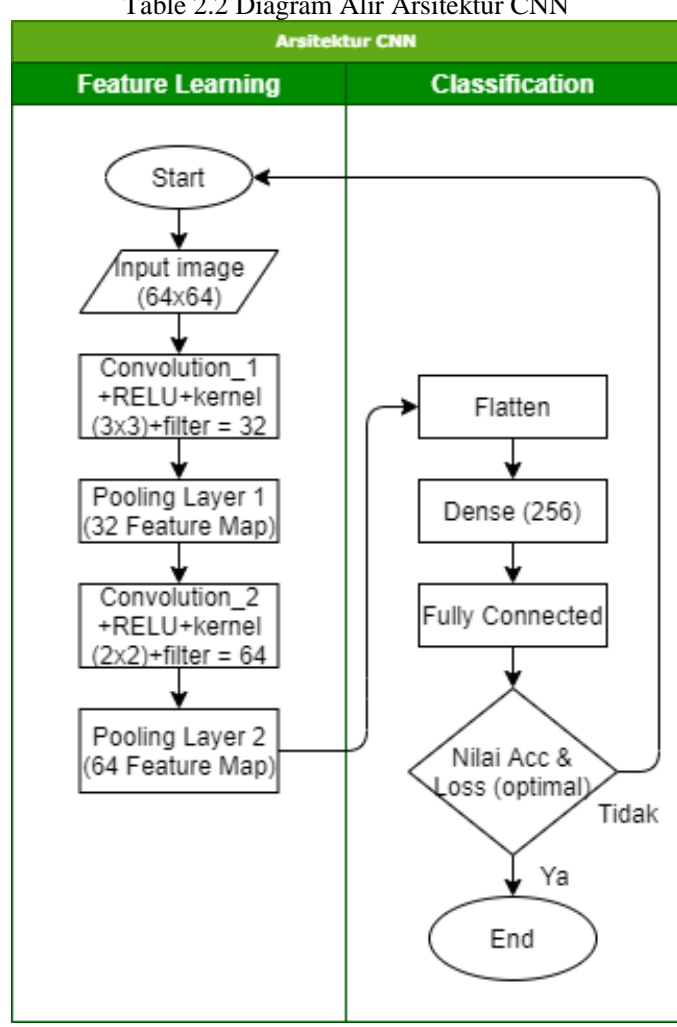

Berdasarkan Tabel 2.2 dijelaskan bahwa terdapat dua tahapan dalam arsitektur $\mathrm{CNN}$, yaitu feature learning dan classification. Feature learning adalah teknik yang memungkinkan sebuag sistem berjalan secara otomatis untuk menentukan representasi dari sebuah image menjadi features yang berupa angka-angka yang mempresentasikan image tersebut. Tahap classification adalah sebuah tahap dimana hasil dari feature learning akan digunakan untuk proses klasifikasi berdasarkan subclass yang sudah ditentukan. Berikut adalah rancangan arsitektur $\mathrm{CNN}$ :

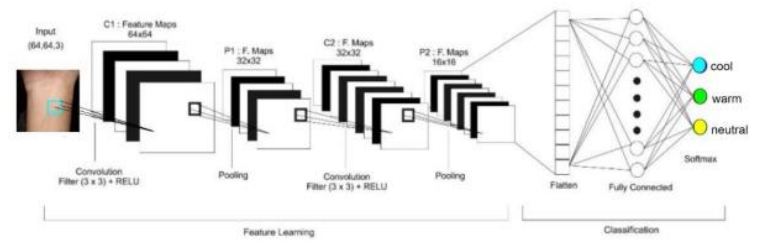

Gambar 2.1 Rancangan arsitektur CNN

Pada Gambar 3.2 merupakan rancangan arsitektur CNN dimana pada konvolusi pertama menggunakan jumlah filter sebanyak 32 dan kernel dengan matriks $3 \times 3$. Kemudian dilakukan proses pooling menggunakan ukuran pooling $2 \times 2$ dengan pergeseran mask sebanyak dua langkah. Kemudian pada tahapan konvolusi kedua 
dengan menggunakan jumlah filter sebanyak 64 dan melalui proses augmentasi tesebut akan diperbanyak kernel dengan matriks 2x2. Kemudian di lanjutkan menjadi 3000 gambar dengan tambahan proses rotate dengan flatten yaitu merubah output dari proses dan zoom.

konvolusi yang berupa matriks menjadi sebuah vector

yang selanjutnya akan diteruskan pada proses klasifikasi Langkah selanjutnya, gambar dibagi dengan dengan menggunakan multi layer perceptron dengan perbandingan 8:2 dimana data train diperbanyak 2400 jumlah neuron pada lapisan tersembunyi yang telah kali sedangkan untuk data test sebanyak 600 kali untuk ditentukan. Kelas dari citra kemudian diklasifikasikan masing-masing kelasnya, sehingga menghasilkan 7800 berdasarkan nilai dari neuron pada lapisan tersembunyi data train dan sebanyak 1800 data test. Sampel data dengan menggunakan fungsi aktivasi softmax.

5. Rancangan Pengujian

gambar asli yang digunakan dapat dilihat pada Gambar Pengujian ini dilakukan untuk melakukan evaluasi terhadap model yang dihasilkan oleh CNN. Pengujian dilakukan dua tahap yaitu tahap training dan tahap testing. Tahap training adalah tahap dimana model CNN diuji dengan data latih yang sudah disediakan. Jumlah data latih yang disediakan sebanyak 2400 data gambar. Tahap testing adalah tahap pengujian model yang sudah dilakukan tahap pelatihan. Jumlah data latih dalam penelitian ini sebanyak 600 data gambar. Pada tahap ini model di uji dengan gambar yang berbeda dengan tujuan menguji apakah model sudah menghasilkan performa yang baik dalam mengklasifikasikan sebuah gambar.

\section{Kesimpulan}

Pada tahap akhir akan dibuat suatu kesimpulan yang berasal dari hasil analisis dan pembahasan data yang data yang telah diuji berdasarkan rumusan masalah. Diharapkan dalam proposal ini dapat menghasilkan klasifikasi tipe undertone dengan akurasi yang baik.

\section{Hasil dan Pembahasan}

\subsection{Hasil Preprocessing}

Pada penelitian ini, dilakukan klasifikasi tiga kelas citra gambar undertone, yaitu cool, warm dan neutral dengan menggunakan algoritma Convolutional Neural Network (CNN). Proses utama dalam pembuatan model ini diawali dengan proses preprocessing. Proses ini merupakan suatu tahap untuk mempersiapkan data mentah menjadi data yang siap digunakan dalam proses berikutnya. Terdapat dua langkah dalam proses preprocessing yaitu augmentasi dan pembagian data.

Untuk proses augmentasi data dilakukan terhadap dataset undertone yang telah dikelompokan menjadi 3 kelas, yang pertama yaitu cool dengan jumlah data gambar sebanyak 36, untuk warm dengan jumlah data gambar sebanyak 37 dan untuk neutral dengan jumlah data gambar sebanyak 32. Selanjutnya memasuki proses augmentasi data, dimana dalam proses tersebut dilakukan perubahan dan peningkatan jumlah data. Augmentasi dilakukan terhadap data gambar yang akan digunakan agar data gambar tidak sebesar gambar asli, sehingga meringankan beban komputer pada saat proses pelatihan. Sebelum memasuki proses augmentasi, resolusi gambar asli telah dirubah menjadi 64x64 piksel,

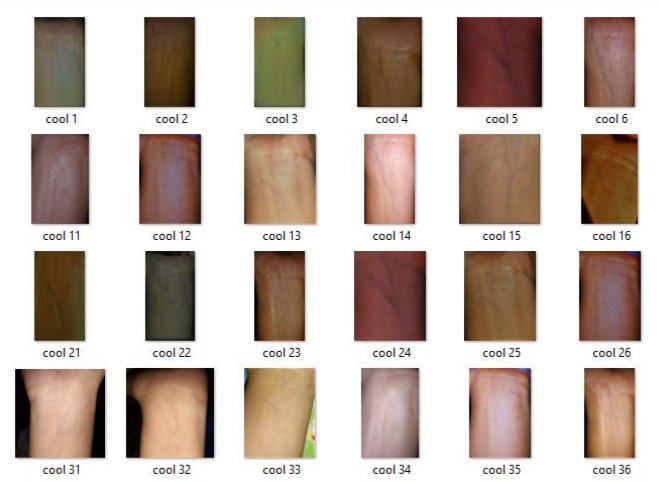

Gambar 3 Data Asli Cool

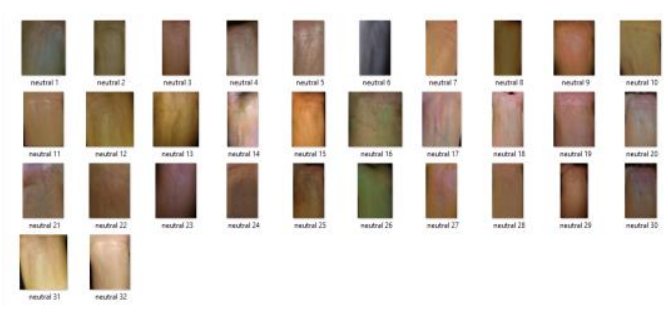

Gambar 3.1 Data Asli Neutral

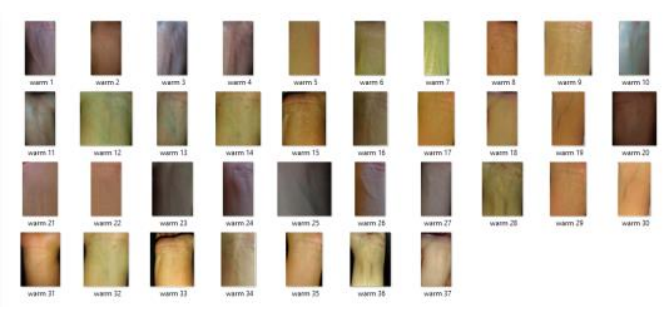

Gambar 3.2 Data Asli Warm

Kemudian melalui proses augmentasi tersebut menghasilkan data yang terdeteksi benar pada data asli yaitu 2364 data train dan 564 data test untuk tipe cool, sedangkan untuk neutral menghasilkan 2368 data train dan 568 data test, serta untuk warm menghasilkan 2363 data train dan 563 data test. Selanjutnya untuk prosesnya bisa dilihat pada gambar dibawah. 


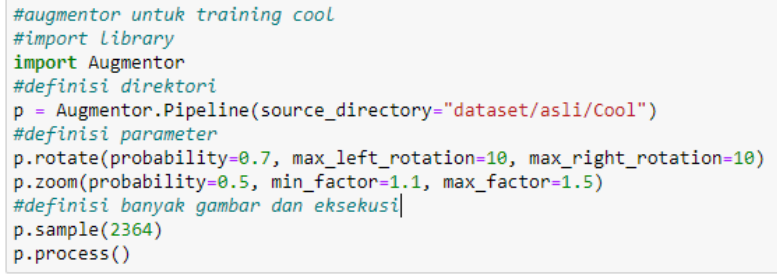

Gambar 3.3 Proses augmentasi untuk training cool

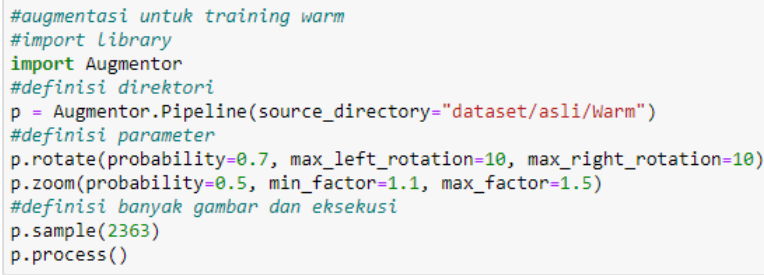

Gambar 3.8 Proses augmentasi untuk training warm

Gambar 3.3 merupakan source code untuk melakukan Gambar 3.8 merupakan source code untuk melakukan augmentasi untuk data training pada tipe undertone cool augmentasi untuk data training pada tipe undertone dengan me-rotate dan men-zoom gambar. warm dengan me-rotate dan men-zoom gambar.

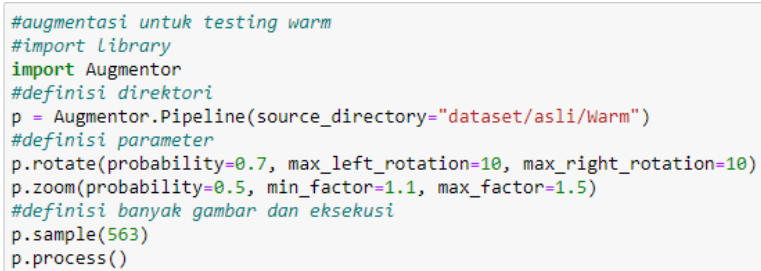

Gambar 3.4 Proses augmentasi untuk testing cool

Gambar 3.9 Proses augmentasi untuk testing warm

Gambar 3.4 merupakan source code untuk melakukan Gambar 3.9 merupakan source code untuk melakukan augmentasi untuk data testing pada tipe undertone cool augmentasi untuk data testing pada tipe undertone dengan me-rotate dan men-zoom gambar.

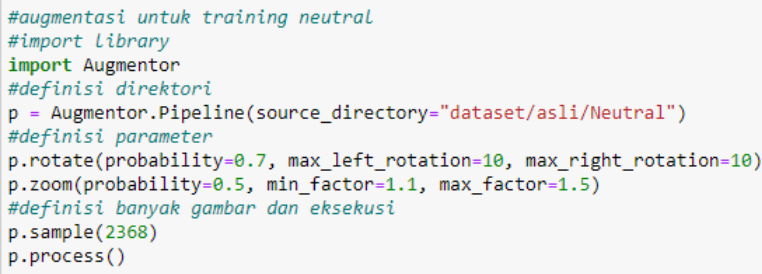

Gambar 3.6 Proses augmentasi untuk training neutral

Gambar 3.6 merupakan source code untuk melakukan augmentasi untuk data training pada tipe undertone neutral dengan me-rotate dan men-zoom gambar.

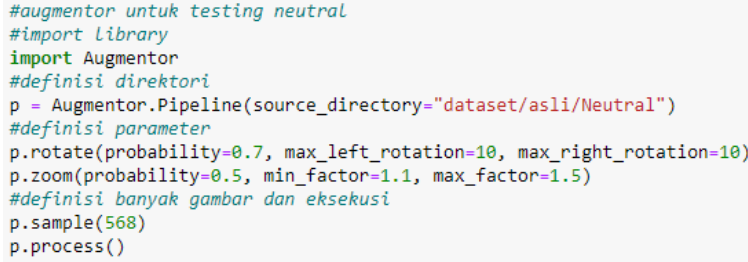

Gambar 3.7 Proses augemntasi untuk testing neutral

Gambar 3.7 merupakan source code untuk melakukan augmentasi untuk data testing pada tipe undertone neutral dengan me-rotate dan men-zoom gambar. neutral dengan me-rotate dan men-zoom gambar.

Dari gambar script diatas merupakan suatu proses augmentasi dan sekaligus pembagian data, file data yang sudah diaugmentasi tersebut akan tertuju pada folder hasil_augmentasi lalu dibagi kedalam data testing dan training. Dalam proses pembagian dataset akan mengakses pada data yang terdapat di "C:\Users\HP\Videos\Skripsildataset $\backslash$ hasil_augmentasi $"$

\subsection{Arsitektur Jaringan}

Proses utama dalam pembuatan model ini diawali dengan proses training data. Proses ini bertujuan untuk pembentukan model yang akan digunakan untuk pengujian data testing. Parameter untuk mengukur tingkat keberhasilan model adalah nilai akurasi. Nilai akurasi model dapat ditentukan dengan melakukan pengujian menggunakan data testing. Proses training menggunakan packages Keras pada python dengan back-end tensorflow. Keras merupakan salah satu modul yang dibuat oleh Google untuk mempermudah dalam research mengenai neural network dan mampu berjalan diatas tensorflow.Gunakan tipe huruf Times New Roman pada seluruh naskah, dengan ukuran huruf 10pt seperti yang telah dicontohkan pada panduan penulisan ini. Jarak spasi adalah single dan isi tulisan atau naskah 
menggunakan perataan kiri-kanan (justified), kecuali pada tabel, gambar dan daftar rujukan.

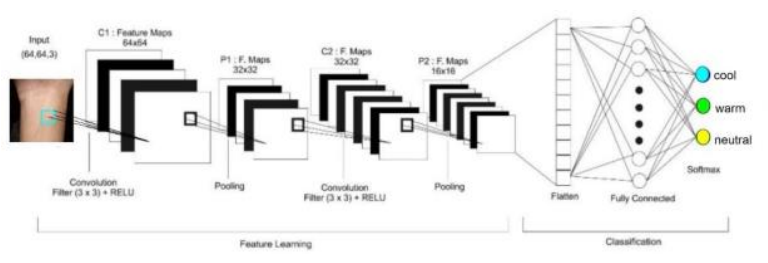

Gambar 4.10 Arsitektur Jaringan

Untuk menghasilkan model optimal. Penelitian ini menggunakan input gambar dengan ukuran $64 \times 64 \times 3$, Berdasarkan uraian penjelasan dari arsitektur jaringan tujuannya untuk membandingkan nilai akurasi diatas, arsitektur tersebut digunakan untuk proses berdasarkan ukuran gambarnya. Arsitektur diatas dapat training. Sehingga dari proses training didapatkan model dijelaskan seperti penjelasan dibawah ini :

1. Proses konvolusi pertama digunakam kernel berukuran $3 \times 3$ dan jumlah filter sebanyak 32 filter, proses konvolusi ini adalah proses kombinasi antara dua buah matriks yang berbeda untuk menghasilkan suatu nilai matriks yang baru. Setelah proses konvolusi, maka ditambahkan sebuah aktivitas fungsi yaitu RELU (Retrified Linear Unit). Fungsi aktivasi ini bertujuan untuk mengubah nilai negative menjadi nol (menghilangkan nilai negative dalam sebuah matriks hasil konvolusi). Hasil konvolusi ini memiliki ukuran yang sama yakni 64x64 karena pada saat proses konvolusi digunakan nilai padding 0 .

2. Proses pooling, merupakan pengurangan ukuran matriks dengan menggunakan operasi pooling. Terdiri dari sebuah filter dengan ukuran tertentu yang akan secara bergantian bergeser pada seluruh area feature map. Penelitian ini menggunakan max-pooling untuk mendapatkan nilai matriks yang baru hasil dari proses poolong. Berdasarkan hasil pooling menghasilkan matriks baru berukuran 32x32 dengan menggunakan kernel pooling $2 \times 2$. Cara kerja maxpooling adalah mengambil nilai paling maksimum berdasarkan pergeseran kernelnya sebanyak nilai stridei yaitu 2 .

3. Proses konvolusi kedua yaitu meneruskan hasil dari proses pooling pertama yakni dengan input matriks gambar sebesar 32x32 dengan jumlah filter sebanyak 64 filter dan ukuran kernel $3 \times 3$. Proses konvolusi kedua ini menggunakan fungsi aktivasi RELU.

4. Proses selanjutnya masuk ke proses pooling yang kedua, proses ini hampir sama dengan proses pooling yang pertama, namun ada perbedaan pada nilai output akhir matriksnya. Output yang dihasilkan memiliki ukuran gambar 16x16.

5. Selanjutnya flatten atau fully connected. Pada tahap ini digunakan hanya satu hidden layer pada jaringan multi layer perceptron. Flatten disini mengubah output pooling layer menjadi sebiah vector. Sebelum melakukan proses klasifikasi atau memprediksi gambar, pada proses ini dugunakan nilai dropout. Dropout adalah sebuah teknik regulasi jaringan syaraf dengan tujuan memilih beberapa neuron secara acak dan tidak akan dipakai selama proses pelatihan, dengan kata lain neuron-neuron tersebut dibuang secara acak. Tujuan dari proses ini yaitu mengurangi overfitting pada saat proses training.

6. Proses terakhir adalah penggunaan aktivasi fungsi Softmax.

dari arsitektur tersebut. Berikut model yang terbentuk:

\begin{tabular}{|l|l|l|l|}
\hline No & \multicolumn{1}{|c|}{ Nama } & \multicolumn{1}{|c|}{ Size } & \multicolumn{1}{|c|}{ Parameter } \\
\hline 0 & Input & $64 * 64 * 3$ & 0 \\
\hline 1 & Conv2d_1 & $\begin{array}{l}(64+(2 * 1)- \\
(3-1))= \\
((3 * 3 * 3)+1) * 32= \\
64 * 64 * 32\end{array}$ & 896 \\
\hline 2 & MaxPool_1 & $32 * 32 * 32$ & 0 \\
\hline 3 & Conv2d_2 & $\begin{array}{l}(32+(2 * 1)- \\
(3-1))=\end{array}$ & $((3 * 3 * 32)+1)^{*} 64=$ \\
& & $32 * 32 * 64$ & \\
\hline 4 & MaxPool_2 & $16 * 16 * 32$ & 0 \\
\hline 5 & Flatten & 16384 & 0 \\
\hline 6 & Dense & 256 & $(16384 * 256)+256=$ \\
& & 3194560 \\
\hline 7 & Output & $(256+1) * 3=771$ \\
\hline
\end{tabular}




\section{Rizka Fayyadhila ${ }^{1}$, Apri Junaidi ${ }^{2}$, Novian Adi Prasetyo ${ }^{3}$ \\ Journal of DINDA (Data Science, Information Technology, and Data Analytics)}

Vol. 1 No. 2 (2021)

Tabel diatas merupakan model yang terbentuk dari hasil a. $\quad$ Position $1=(3 \times 1)+(5 \times(-1)+(1 \times 1)+(1 \times(-1))$ training. Untuk menghitung input kedalam $+(5 \times 1)+$ konvolutional digunakan rumus "input size + $2^{*}$ padding - (filter_size $\left.=1\right)$ ". Total parameter yang $(3 \mathrm{x}(-1))+(3 \mathrm{x} 1)+(7 \mathrm{x}(-1))+(8 \mathrm{x} 1)=-10$ terbentuk dari model sebanyak 4.214 .723 neuron.

\subsubsection{Proses Convolutional Layer}

Konvolusi merupakan proses mengkombinasi dua buah deret angka yang menghasilkan deret angka yang ketiga. c. $\quad$ Position $3=(3 \times 1)+(7 \times(-1)+(8 \times 1)+(1 \times(-1))$ Jika di implementasikan angka pada konvolusi akan $+(1 \mathrm{x} 1)+$ berbentj matriks array. Pada input, gambar memiliki ukuran 64x64 piksel, yang menunjukan bahwa tinggi dan lebar piksel dari gambar sebesar 64 dan gambar d. Position $4=(5 \times 1)+(1 \times(-1)+(2 \times 1)+(5 \times(-1))$ tersebut memiliki 3 channel yaitu RGB. Setiap channel $+(3 \times 1)+$ piksel memiliki nilai matriks yang berbeda-beda. Input akan di konvolusi dengan nilai filter yang sudah ditentukan. Filter merupakan blok lain atau kubus e. Position $5=(5 \times 1)+(3 \times(-1)+(2 \times 1)+(7 \times(-1))$ dengan tinggi dan lebar yang lebih kecil namun dengan $+(8 \times 1)+$ kedalaman yang sama. Filter digunakam untuk menentukan pola apa yang akan dideteksi yang $(1 \times(-1))+(1 \times 1)+(1 \times(-1))+(4 \times 1)=0$ selanjutnya dikonvolusi atau dikalikan dengan nilai f. $\quad$ Position $6=(7 \times 1)+(8 x(-1)+(1 \times 1)+(1 \times(-1))$ matriks. Jumlah filter pada konvolusi ini sebanyak $64+(1 \times 1)+$ piksel dengan ukuran kernel $(3 \times 3)$ dengan arti bahwa gambar yang dihasilkan dari konvolusi akan sebanyak 64 fitur map.

\begin{tabular}{|l|l|l|l|l|}
\hline 3 & 1 & 3 & 1 & 4 \\
\hline 5 & 5 & 7 & 1 & 2 \\
\hline 1 & 3 & 8 & 1 & 6 \\
\hline 2 & 2 & 1 & 4 & 4 \\
\hline 5 & 3 & 2 & 6 & 7 \\
\hline \multicolumn{5}{|c|}{$5 \times 5$}
\end{tabular}

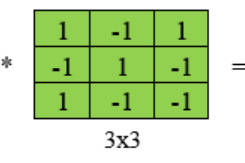

Gambar 4.11 Perhitungan Proses Konvolusi

Gambar 5.4 menunjukan proses konvoluso dengan $+(4 \times 1)+$ menggunakan ukuran kernel 3x3, dengan menggunakan stride 1. Stride artinya jumlah pergeseran kernel terhadap matriks input berjumlah satu. Jika divisualisasikan sebagai berikut:
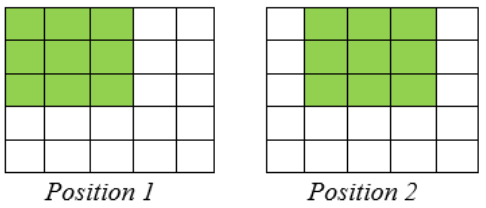

Position 2

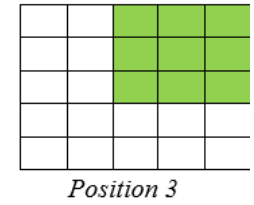

Gambar 4.12 Posisi Kernel Pada Konvolusi

Gambar 4.12 menunjukan perhitungan dot product pada proses konvolusi dimana sebuah kernel ukuran $3 \times 3$ yang dimulai pada sisi bagian kiri. Proses ini disebut dengan sliding window. Pada penelitian ini diberikan nilai padding 1 , yaitu adanya penambahan nilai 0 disekeliling nilai matriks input supaya input dan output memiliki nilai matriks yang sama, sehingga tidak mengurangi informasi-informasi pada gambar. Proses ini dilakukan dari ujung kiri atas sampai ujung kiri bawah. Perhitungan dot product dapat dilihat sebagai berikut:

$$
(4 \mathrm{x}(-1))+(2 \mathrm{x} 1)+(6 \mathrm{x}(-1))+(4 \mathrm{x} 1)=-12
$$$$
\text { g. } \quad \text { Position } 7=(1 \times 1)+(2 \times(-1)+(5 \times 1)+(3 \times(-1))
$$$$
+(2 \times 1)+
$$$$
(3 \mathrm{x}(-1))+(8 \mathrm{x} 1)+(1 \mathrm{x}(-1))+(2 \mathrm{x} 1)=7
$$

h. Position $8=(3 \mathrm{x} 1)+(2 \mathrm{x}(-1)+(3 \mathrm{x} 1)+(8 \mathrm{x}(-1))$ $+(1 \times 1)+$

$$
(2 \mathrm{x}(-1))+(1 \mathrm{x} 1)+(4 \mathrm{x}(-1))+(6 \times 1)=-16
$$

i. $\quad$ Position $9=(8 \times 1)+(1 \times(-1)+(2 \times 1)+(1 \times(-1))$

$$
(6 \mathrm{x}(-1))+(6 \mathrm{x} 1)+(4 \mathrm{x}(-1))+(7 \mathrm{x} 1)=1
$$

Sebelum dilanjutkan ke proses pooling layer, untuk menghilangkan nilai negative pada hasil, maka pada arsitektur jaringan digunakan aktivasi ReLU setelah proses konvolusi. Fungsi dari aktivasi ini adalah dengan malukan threshold dari 0 hingga infinity. Nilai yang ada pada hasil konvolusi yang bernilai negative akan diubah dengan aktivitas ini menjadi nol dan yang lainnya sampai infinity.

\subsubsection{Proses Pooling}

Pooling merupakan pengurangan ukuran matriks dengan menggunakan operasi pooling (penggabungan). Metode yang digunakan dalam proses pooling ini menggunakan max-pooling. Max-pooling merupakan salah satu metode umum yang bisa digunakan oleh peneliti yang berkaitan dengan deep learning. Berikut merupakan gambaran dari max-pooling: 


\begin{tabular}{|c|c|c|}
\hline 10 & 8 & 2 \\
\hline 0 & 0 & 12 \\
\hline 7 & 16 & 1 \\
\hline
\end{tabular}$=$\begin{tabular}{|c|c|}
\hline 10 & 12 \\
\hline 16 & 16 \\
\hline
\end{tabular}

Gambar 4.13 Proses Pooling

Proses pooling ini menggunakan ukuran $2 \times 2$ dengan stride 1 dimana jumlah pergeseran kernel terhadap matriks input berjumlah satu. Dalam proses pooling ini digunakan metode max-pooling, dimana window akan bergeser sesuai dengan ukuran dan stridenya untuk mendapatkan nilai paling maksimum. Terlihat pada gambar 4.13 output dari proses ini memiliki nilai yang paling maksimum yang di ambik dari matriks fitur map hasil konvolusi. Hasil max-pooling tersebut berukuran $2 \times 2$.

\subsubsection{Proses Fully Connected}

Selanjutnya adalah fully connected layer. Proses ini bertujuan untuk melakukan transformasi pada dimensi data agar data dapat diklasifikasikan secara linear.

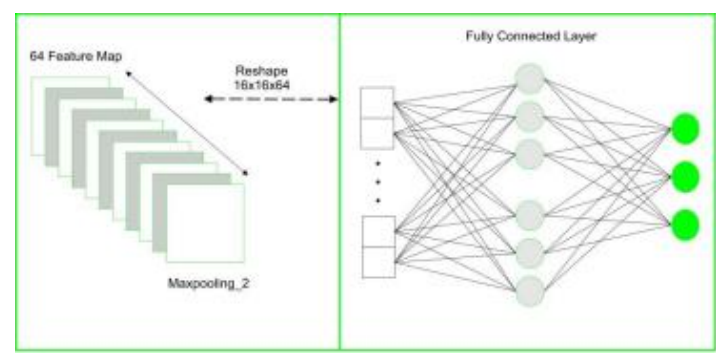

Gambar 4.14 Proses Fully Connected Layer

Gambar 4.14 merupakan proses converting hasil fitur map max-pooling menjadi flatten atau vector. Dalam a. proses ini nilai input matriks dari layer sebelumnya akan diubah menjadi vector. Jaringan ini umumnya 1 . menggunakan lapisan yang terhubung sepenuhnya di cool. mana setiap piksel dianggap sebagai neuron terpisah. Dalam proses ini biasanya diterapkan metode dropout. 2 . Metode ini bertujuan untuk menonaktifkan beberapa edge yang terhubung ke setiap neuron untuk 3 . menghindari overfiting. Setelah itu proses terakhir adalah klasifikasi. Dalam proses ini digunakan aktivasi Kesimpulannya untuk hasil model dapat memprediski fungsi softmax. Aktivasi ini akan membantu untuk benar pada kelas cool sebesar 596/600\% =99, 33\% mengklasifikasikan input terhadap targetnya yaitu kedalam 3 kelas undertone.

b. Warm

\subsection{4. $\quad$ Model Hasil Training}

Setelah melalui beberapa proses dalam algoritma Convolutional Neural Network didapatkan hasil 2. training. Proses ini menggunakan jumlah 30 epoch, nilai learning rate 0.001 . Berikut grafik hasil training:
1. Terdapat 598 gambar yang terdeteksi benar warm.
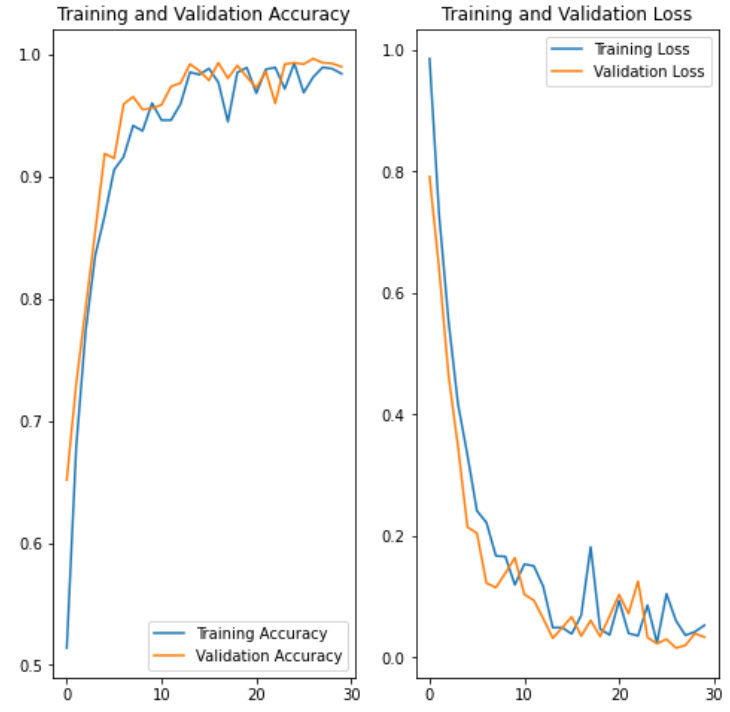

Gambar 4.15 Training Graph

Berdasarkan gambar 4.15 accuracy dan training model mencapai $98 \%$ dengan nilai loss sebesar 0, 0214. Proses training disini menggunakan learning rate 0.001 dengan input gambar sebesar 64x64 piksel. Waktu pelatihan yang dibutuhkan untuk 30 epoch dalam menjalankan training model ini yaitu 210 menit. Semakin banyak epoch maka semakin lama waktu yang dibutuhkan untuk training model. Kemudian accuracy dari data validation mencapai 99\% dengan nilai loss sebesar 0, 0239 .

\subsubsection{Hasil Testing}

Setelah dilakukan pengujian diperoleh hasil terdeteksi benar pada masing-masing kelas yaitu:

\section{Cool}

Terdapat 596 gambar yang terdeteksi benar

Terdapat 3 gambar yang salah dideteksi neutral.

Tedapat 1 gambar yang salah dideteksi warm.

Terdapat 2 gambar yang salah dideteksi neutral.

3. Terdapat 0 gambar yang salah terdetekdi cool. 
Kesimpulannya untuk hasil model dapat memprediksi 3.4 Headings

benar pada kelas warm sebesar 598/600\% $=99,67 \%$

c. Neutral

1. Terdapat 597 gambar yang benar dideteksi 3.5 Bullet dan Numbering neutral.

2. Terdapat 3 gambar yang salah dideteksi warm.

3. Terdapat 0 gambar yang salah dideteksi cool.

Kesimpulannya untuk hasil model dapat memprediksi benar pada kelas neutral sebesar 597/600 \% = 99, 5\%

\begin{tabular}{|c|c|c|c|}
\hline & A & B & C \\
\hline A & 596 & 1 & 3 \\
\hline B & 0 & 598 & 2 \\
\hline C & 0 & 3 & 597 \\
\hline
\end{tabular}

Tabel 4.2 Perhitungan Akurasi

Tabel 4.2 merupakan tabel perhitungan akurasi dimana terdapat beberapa warna. Warna kuning menunjukan kelas prediksi, warna oren sebagai kelas actual dan warna ungu sebagai letak fungsi True Positif.

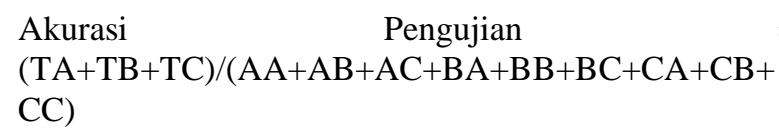

)$/ 1800 \times 100$

$5 \%$

$=99$,

Dari hasil perhitungan menggunakan confussion matrix untuk mengetahui nilai akurasi dari model yang dibuat menghasilkan nilai sebesar 99,5 \%, maka dapat disimpulkan bahwa model yang telah dibuat memiliki akurasi yang cukup tinggi.

\subsection{Layout Naskah}

Cara mudah membuat layout adalah dengan menggunakan panduan ini secara langsung.
Gunakan style heading dalam template ini secara langsung. Style sudah diformat sedemikian rupa sehingga memberikan jarak heading yang sesuai.

Pada dasarnya disarankan untuk tidak menggunakan numbering $(1,2,3 \ldots$, a,b,c dst) dalam pembahasan naskahnya, ubah menjadi dalam bentuk kalimat. Hindari menggunakan Bullet/daftar berurut dengan simbol *, dan lainnya.

\section{Kesimpulan}

Berdasarkan hasil dan pembahasan terkait klasifikasi citra undertone menggunakan algoritma Convolutional Neural Network (CNN) berdasarkan analisis yang telah dilakukan, diperoleh beberapa kesimpulan yaitu:

1. Bahwa dalam pengimplentasian algortma CNN untuk mengklasifikasikan citra undertone berhasil dengan sangat baik dengan hasil akurasi pengujian model sebesar $99,61 \%$

2. Model CNN pada penelitian ini menggunakan input berukuran $64 \times 64$, jumlah epoch 30 , data training 2400 dan data testing 600. Menghasilkan tingkat akurasi training dan testing dalam melakukan klasifikasi citra gambar undertone sebesar $98 \%$ training dan $99 \%$ testing.

\section{= Ucapan Terimakasih [jika ada]}

Sebutkan nama pemberi dana dan pemberi fasilitas yang membantu.

\section{Daftar Rujukan}

[1] A. J. Pitoyo and H. Triwahyudi, "DINAMIKA PERKEMBANGAN ETNIS DI INDONESIA DALAM KONTEKS PERSATUAN NEGARA," Populasi, vol. 25, pp. 64-81, 2017.

[2] F. D. R. Sari, R. H. Sudrajat and I. I. Wahyuni, "REPRESENTASI CANTIK PEREMPUAN INDONESIA DALAM IKLAN TELEVISI CITRA HANDBODY LOTION "DARI CITRA UNTUK PEREMPUAN INDONESIA"," Jurnal Sosioteknologi, vol. XV, pp. 86-95, 2016.

[3] M. Silvana and R. Kurnia, "SISTEM PENDETEKSIAN KESERASIAN WARNA KULIT DAN BUSANA SECARA OTOMATIS UNTUK JENIS KELAMIN PEREMPUAN BERBASIS IMAGE PROCESSING," Jurnal Nasional Teknik Elektro, vol. III, pp. 18-24, 2014.

[4] L. D. Elianti and V. I. S. Pinasti, "MAKNA 
PENGGUNAAN MAKE UP SEBAGAI [8] "The Body Shop," Skin Tone Vs. Undertone, 7 IDENTITAS DIRI," Jurnal Pendidikan Sosiologi, October 2019.

pp. 1-18, 2017.

[5] R. Kristiani and A. Puspitorini, "TATA RIAS KOREKTIF UNTUK WARNA KULIT GELAP PADA PENGANTIN BRIDAL," e-Journal , vol. VI, pp. 80- 85, 2017.

[6] I. P. Sari, "Rekonstruksi dan Manipulasi Simbol Kecantikan," J u r n a l H a w a, vol. I, pp. 1-18, 2019.

[7] R. Puspa, "Isu Ras dan Warna Kulit dalam Konstruksi Kecantikan Ideal Perempuan," vol. XXIII, pp. 312-323, 2020.
[9] R. Asmara and A. , "Pengolahan Data Rehabilitas Penyalahgunaan Narkoba Pada Klinik Aqilah Payakumbih," Jurnal J-Click, vol. IV, pp. 74-83, 2017.

[10] I. W. S. E.P, A. Y. Wijaya and R. Soelaiman, "Klasifikasi Citra Menggunakan Convolutional Neural Network (CNN) pafa Caltech 101," Jurnal Teknik ITS, vol. V, no. 1, pp. 65-69, 2016.

11] F. Kirom, "Studi Literatur : MacamMacam Metode Menggunakan Pendekatan Deep Learning dan Contoh Penerapannya," Malang, 2016. 